University of Nebraska - Lincoln

DigitalCommons@University of Nebraska - Lincoln

\title{
Cytogenetic assignment of 53 microsatellites from the USDA- MARC porcine genetic map
}

\author{
N. L. Lopez-Corrales \\ Roslin Institute \\ C. W. Beattie \\ University of Minnesota \\ G. A. Rohrer \\ USDA-ARS, gary.rohrer@ars.usda.gov
}

Follow this and additional works at: https://digitalcommons.unl.edu/usdaarsfacpub

Part of the Agricultural Science Commons

Lopez-Corrales, N. L.; Beattie, C. W.; and Rohrer, G. A., "Cytogenetic assignment of 53 microsatellites from the USDA-MARC porcine genetic map" (1999). Publications from USDA-ARS / UNL Faculty. 713.

https://digitalcommons.unl.edu/usdaarsfacpub/713

This Article is brought to you for free and open access by the U.S. Department of Agriculture: Agricultural Research Service, Lincoln, Nebraska at DigitalCommons@University of Nebraska - Lincoln. It has been accepted for inclusion in Publications from USDA-ARS / UNL Faculty by an authorized administrator of DigitalCommons@University of Nebraska - Lincoln. 


\title{
Cytogenetic assignment of 53 microsatellites from the USDA-MARC porcine genetic map
}

\author{
N.L. Lopez-Corrales, C.W. Beattie, and G.A. Rohrer \\ US Meat Animal Research Center (MARC), Agricultural Research Service, US Department of Agriculture, \\ Clay Center, NE (USA)
}

\begin{abstract}
This study provides 53 new fluorescent in situ hybridization cytogenetic assignments for microsatellite markers linked on the swine genetic map. Forty microsatellites are physically assigned for the first time. The chromosomal locations of eight markers were either confirmed or refined, while five loci were assigned to locations different from those given in previous reports. Markers were selected to provide physical anchors based on their presumed proximity to centromeres or telomeres and at approximately $30 \mathrm{cM}$ intervals across the genetic map. The number of physical anchors for pig (SSC) chromosomes 8,15 , and 18 linkage groups was significantly
\end{abstract}

improved. Centromeric regions were localized to areas less than $10 \mathrm{cM}$ for SSC 1, 2, 3, 6, 7, 8, and 9. Although the recombination rate was generally higher across small biarmed chromosomes and lowest for large acrocentric chromosomes, two regions with particularly low ( $1 \mathrm{q} 2.1 \rightarrow \mathrm{q} 2.9$ and $13 \mathrm{q} 2.3 \rightarrow \mathrm{q} 4.1)$ and three regions with extremely high $(5 \mathrm{p} 1.5 \rightarrow \mathrm{p} 1.2$, $6 \mathrm{p} 1.4 \rightarrow \mathrm{pl} .3$, and $12 \mathrm{p} 1.5 \rightarrow \mathrm{pl} 1.4)$ rates of recombination were detected. These assignments represent an overall $10 \%$ increase in the number of physically assigned markers in Sus scrofa and more than a $20 \%$ increase in the number of Type II loci assigned to the pig cytogenetic map.
Livestock genetic maps are being used to identify regions of the genome that influence economically important traits (Georges et al., 1993; Andersson et al., 1994). Linkage maps have been established for the domestic pig, Sus scrofa (SSC) (Archibald et al., 1995; Marklund et al., 1996; Rohrer et al., 1996). The highest resolution map available (Rohrer et al.,1996) merged previously published maps by typing 1,042 loci spanning $2,286.2 \mathrm{cM}$. It was anchored to the cytogenetic map with 123 physical assignments, including 68 microsatellite markers developed from cosmids and assigned by fluorescence in situ hybridization (FISH) (Alexander et al., 1996). Although alignment of the maps demonstrated that each linkage group covers the entire length of most chromosomes, an increase in

N.L.L.-C.'s present address is the Roslin Institute, Roslin, Midlothian, EH25 9PS Scotland (UK). C.W.B.'s present address is the University of Minnesota College of Veterinary Medicine, 1971 Commonwealth Avenue, St. Paul, MN 55108 (USA).

Received 17 November 1998; revision accepted 29 January 1999.

Request reprints from Dr. Gary A. Rohrer, US Meat Animal Research Center, PO Box 166, Spur 18D, Clay Center, NE 68933-0166 (USA);

telephone: 402-762-4365; fax: 402-762-4390;

e-mail: rohrer@email.marc.usda.gov. the number of physically assigned, genetically mapped markers would provide a more robust estimate of genetic to physical map distances for specific regions of the genome and improve estimates of chromosomal coverage. This information is essential to construct a contiguous set of genomic clones and to isolate genes for quantitative trait loci (QTL) defined only by genetic map intervals.

Yerle et al. (1997) have summarized physical assignments for 436 loci in the pig, including those made by direct in situ single copy-polymerase chain reaction (DISC-PCR; Troyer et al., 1995), somatic cell hybrid, and in situ hybridization for Type I and II loci. This synopsis represents the most extensive physical map in a livestock species. However, chromosomal regions devoid of anchor markers still remain in the pig genome, and several reported assignments are not in agreement with either the genetic map or other physical assignments for the same locus. In addition, estimates of the location of centromeres within the genetic map and the extent of coverage in telomeric regions need to be improved.

In this study, clones containing 53 microsatellite markers from the USDA-MARC porcine linkage map (Rohrer et al., 1996) were physically assigned by FISH. These new assignments complement a previous set of physically assigned mark- $\begin{array}{ll}\text { KARGER } & \text { Fax }+41613061234 \\ \text { E-mail karger@karger.ch }\end{array}$ E-mail karger@k
(1) 1999 S. Karger AG, Basel 0301-0171/99/0842-0140\$17.50/0
Accessible online at:

http://BioMedNet,com/karger 
ers (Alexander et al., 1996) and cover chromosomal regions currently devoid of physically assigned, informative markers in the USDA-MARC porcine genetic map.

\section{Materials and methods}

\section{Marker source}

Pig microsatellites were chosen from the USDA-MARC porcine linkage map (Rohrer et al., 1996). Markers located either at the telomeric ends or near the centromeric regions of the short and long arms of each linkage group were selected to be physically assigned by FISH. Additional markers were chosen to provide anchor loci at 30-cM intervals throughout the genetic map. In addition, marker SW2410 was reassigned using the same clone and procedures described by Alexander et al. (1996), as its current assignment conflicts with the genetic map. Information about microsatellites is accessible via the world-wide web at http://www.marc.usda.gov/.

\section{$Y A C$ isolation and FISH procedures}

Clones for each probe were isolated from a porcine yeast artificial chromosome (YAC) library by PCR (Alexander et al., 1997). Total yeast DNA was isolated and labeled with biotin-dUTP using a Bionick nick-translation kit according to the manufacturer's instructions (Boehringer Mannheim). Probes were hybridized to R-banded chromosomes isolated from peripheral whole blood short term cell cultures according to Lemieux et al. (1992), as modified by Ponce de Leon (1996). All hybridizations were conducted according to Lichter et al. (1990) except $2 \mu \mathrm{g}$ of total yeast DNA was labeled, and between 7.5 and $15 \mu \mathrm{g}$ of porcine genomic DNA was used as a competitor.

\section{Digital imaging and probe localization}

Fluorescein isothiocyanate (FITC) and propidium iodide (PI) were excited with a BP450-490 filter (Zeiss). Fluorescent signals were obtained using a Zeiss Axioscope epifluorescence microscope coupled to a cooled CCD camera (Nikon), recorded, and photographed separately from the display monitor. Images of banded chromosomes and fluorescent marker signals were superimposed in order to determine the physical position. Cytogenetic locations were assigned according to the standardized pig G-banding pattern and nomenclature (Committee for the Standardized Karyotype of the Domestic Pig, 1988).

\section{Results}

Fifty-three clones (52 YAC clones and one cosmid) containing mapped microsatellites were physically assigned with FISH. Twenty-two $(42.3 \%)$ of the 52 YAC clones analyzed hybridized to more than one genomic region. Twenty-one of these 22 YAC clones contained only a single YAC insert. The most probable explanation is that these 21 YAC clones are chimeric; however, it is also possible that a YAC clone contains a DNA segment that hybridizes to multiple genomic regions (due to repetitive elements or gene families). The other clone contained two different YAC inserts. All remaining clones hybridized to specific regions of the genome, as determined by examining at least 10 metaphase spreads. Although the level of chimerism detected for the YAC library of Alexander et al. (1997) was considerably higher in this study (42\%) than previously reported (28\%), these frequencies do not differ significantly $\left(\chi^{2}=1.46\right.$ with one degree of freedom). The actual level of chimerism in the YAC library is likely to be between $28 \%$ and $42 \%$.

For YACs that hybridized to more than one chromosome, the hybridization signal present on the chromosome the microsatellite was previously assigned to by linkage was presumed to be the correct physical assignment for that particular genetic marker. In other experiments, subcloning YACs that hybridized to multiple chromosomes yielded genetic markers for both chromosomal regions five out of seven times. (However, only two genetic markers were developed from each of the YACs that did not produce markers for both regions.) There were no instances where a clone hybridized to more than one region of the same chromosome. Hybridization of marker SW949 to both the $\mathrm{X}$ and $\mathrm{Y}$ chromosomes was assumed to be region specific, since this marker resides in the pseudoautosomal region of the X chromosome (Rohrer et al., 1996).

Markers were assigned to each chromosome, except SSC 6 (Fig. 1). An average of 2.7 assignments per chromosome were made. Chromosomes 1,8 , and 15 had the highest number of newly assigned markers (six, seven, and six, respectively). Four markers were assigned to SSC 9, 13, and X; three markers to SSC 4 and 11; two markers to SSC 2, 3, 5, 10, 12, and 18; and one marker to SSC 7, 14, 16, 17, and Y.

\section{Discussion}

Our objective was to provide new physical assignments to improve the integration of the porcine linkage and physical maps by essentially covering those regions devoid of anchors. The total number of assigned markers represents a $10 \%$ increase in physically assigned sequences (Yerle et al., 1997) and a $39 \%$ increase in Type II anchor loci present in the MARC porcine genetic map (Rohrer et al., 1996). Markers were assigned to telomeric bands for 13 chromosomal regions (SSC $1 \mathrm{p}, 3 \mathrm{p}, 4 \mathrm{q}, 5 \mathrm{q}, 9 \mathrm{p}, 9 \mathrm{q}, 10 \mathrm{q}, 12 \mathrm{q}, 13 \mathrm{q}, 15 \mathrm{q}, 18 \mathrm{q}, \mathrm{Xp}$, and Xq). The location of the centromere on the genetic map has been resolved to regions less than $10 \mathrm{cM}$ for seven chromosomes (SSC 1, 2, 3, 6, 7, 8, and 9); between 10 to $15 \mathrm{cM}$ for SSC 4, 5 and 10; and greater than $15 \mathrm{cM}$ for SSC 11, 12 and X.

Forty markers were assigned for the first time and 13 were either confirmed or reassigned to a new cytogenetic location by FISH. Table 1 presents our assignments, along with previous assignments for these 13 markers. Marker SW2410 was reassigned to SSC 8p2.3 based on FISH analysis of the same cosmid previously used to assign the marker by Alexander et al. (1996) to SSC $8 \mathrm{p} 2.2$. Our new assignment to SSC $8 \mathrm{p} 2.3$ is in agreement with the linkage map. We have assigned SW936 to SSC $15 q 2.5$, whereas Milan et al. (1996) had assigned it to SSC $15 \mathrm{q} 2.1 \rightarrow \mathrm{q} 2.2$ through the use of DISC-PCR. One possible reason for this discrepancy could be due to inherent differences in the techniques. Our assignment of SW936 to SSC $15 \mathrm{q} 2.5$ is supported by other FISH assignments in this study relative to the linkage map. Initial results of DISC-PCR from Troyer et al. (1995) also tended to show small discrepancies with results from FISH and linkage. The remaining 11 markers in Table 1 were previously assigned indirectly by typing somatic cell hybrid panels (Rettenberger et al., 1995; Yerle et al., 1996). Most assignments were in agreement, but all discrepancies were minor.

These results demonstrate that the highest resolution porcine linkage map currently available (Rohrer et al., 1996) spans a majority of the genome, including two areas reported by Yerle 

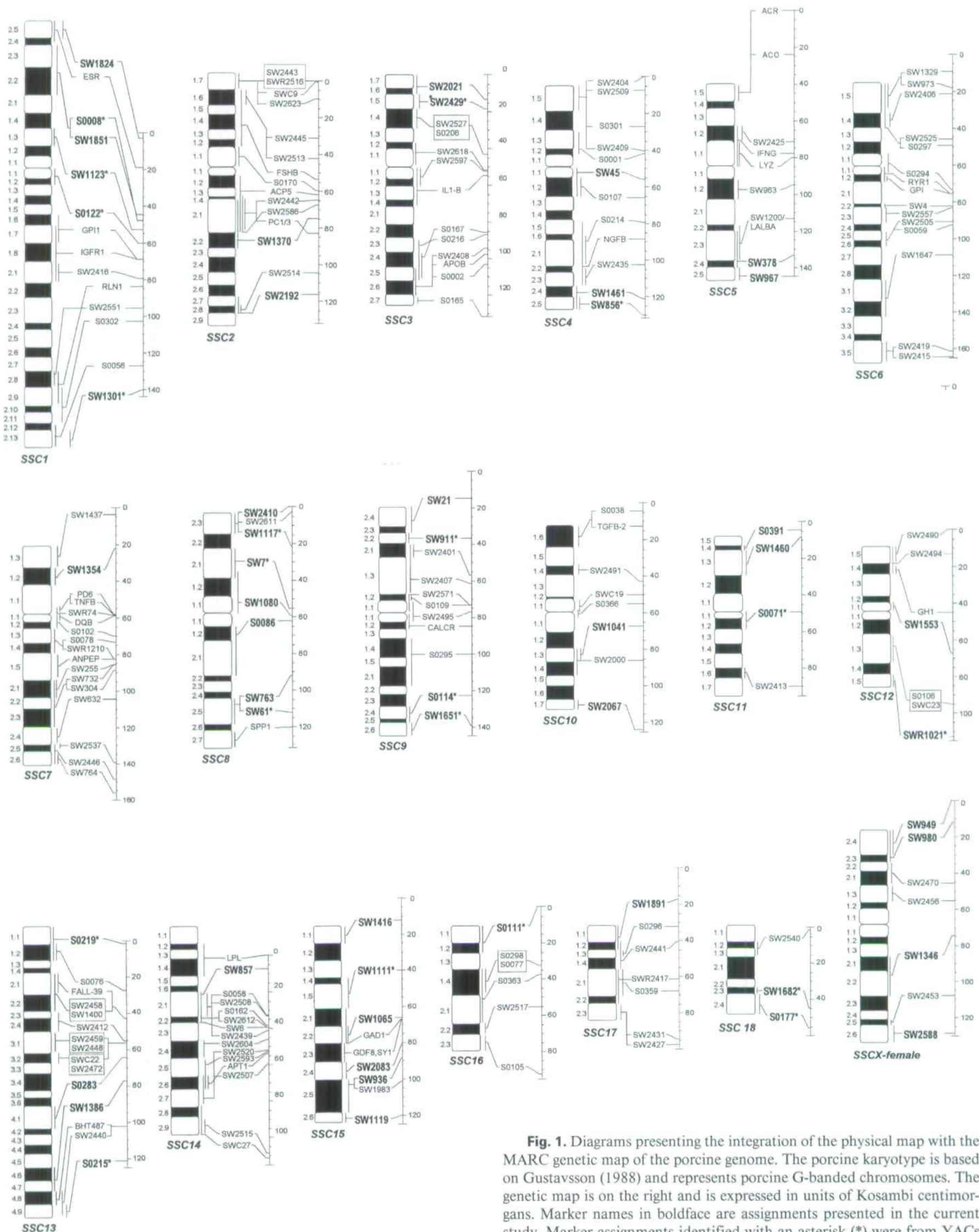

Fig. 1. Diagrams presenting the integration of the physical map with the MARC genetic map of the porcine genome. The porcine karyotype is based on Gustavsson (1988) and represents porcine G-banded chromosomes. The genetic map is on the right and is expressed in units of Kosambi centimorgans. Marker names in boldface are assignments presented in the current study. Marker assignments identified with an asterisk $\left({ }^{*}\right)$ were from YACs presumed to be chimeric, whereas the assignment of SW1891 to SSC $17 \mathrm{q} 1.2 \rightarrow \mathrm{q} 2.1$ was from a host containing two YAC inserts. All physical assignments included are based on in situ hybridization. 
Table 1. Comparison of physical assignments for 13 previously assigned markers included in this study

\begin{tabular}{lllll}
\hline Marker & $\begin{array}{l}\text { Current FISH } \\
\text { assignment }\end{array}$ & $\begin{array}{l}\text { Previous } \\
\text { assignment }\end{array}$ & Method $^{a}$ & Reference \\
\hline S0008 & $1 \mathrm{p} 2.3 \rightarrow \mathrm{p} 2.2$ & $1 \mathrm{p} 2.3 \rightarrow \mathrm{p} 2.2$ & $\mathrm{SH}$ & Robic et al. (1996) \\
S0122 & $1 \mathrm{q} 1.1 \rightarrow \mathrm{q} 1.2$ & $1 \mathrm{q} 1.1 \rightarrow \mathrm{q} 1.7$ & SH & Robic et al. (1996) \\
SW45 & $4 \mathrm{q} 1.1 \rightarrow \mathrm{q} 1.2$ & 4 & SH & Rettenberger et al. (1995) \\
SW378 & $5 \mathrm{q} 2.3 \rightarrow \mathrm{q} 2.4$ & $5 \mathrm{q} 2.5$ & SH & Robic et al. (1996) \\
SW2410 & $8 \mathrm{p} 2.3$ & $8 \mathrm{p} 2.2$ & FISH & Alexander et al. (1996) \\
SW7 & $8 \mathrm{p} 2.2$ & 8 & SH & Rettenberger et al. (1995) \\
S0086 & $8 \mathrm{q} 1.2 \rightarrow \mathrm{q} 2.1$ & $8 \mathrm{q} 1.1 \rightarrow \mathrm{q} 1.2$ & SH & Robic et al. (1996) \\
SW911 & $9 \mathrm{p} 2.2$ & $9 \mathrm{p} 2.1 \rightarrow \mathrm{p} 1.3$ & SH & Robic et al. (1996) \\
S0114 & $9 \mathrm{q} 2.4 \rightarrow \mathrm{q} 2.5$ & $9 \mathrm{q} 2.1 \rightarrow \mathrm{q} 2.6$ (or $9 \mathrm{q} 1.1)$ & SH & Robic et al. (1996) \\
SW1041 & $10 \mathrm{q} 1.3$ & $10 \mathrm{q} 1.4 \rightarrow \mathrm{q} 1.6$ & SH & Robic et al. (1996) \\
SW1111 & $15 \mathrm{q} 1.4 \rightarrow \mathrm{q} 1.5$ & $15 \mathrm{q} 1.5 \rightarrow \mathrm{q} 2.2$ & SH & Robic et al. (1996) \\
SW936 & $15 \mathrm{q} 2.5$ & $15 \mathrm{q} 2.1 \rightarrow \mathrm{q} 2.2$ & DISC-PCR & Milan et al. (1996) \\
SW1119 & $15 \mathrm{q} 2.6$ & $15 \mathrm{q} 1.5 \rightarrow \mathrm{q} 2.2$ & SH & Robic et al. (1996) \\
\hline
\end{tabular}

a $\mathrm{SH}=$ somatic cell hybrid analysis; DISC-PCR $=$ direct in situ single copy-polymerase chain reaction; FISH = fluorescence in situ hybridization. et al. (1997) not to be covered in the linkage maps (SSC $15 \mathrm{q} 1.1 \rightarrow \mathrm{q} 1.2$ and $18 \mathrm{q} 1.2)$. However, SSC $11 \mathrm{q} 1.7,14 \mathrm{q} 1.1$, and $18 \mathrm{q} 1.1$ still appear to lack genetic and physically assigned markers. These three regions represent a total of approximately $36.5 \mathrm{Mb}$, or $1.3 \%$ of the porcine genome based on the standard karyotype and chromosome size reported by Schmitz et al. (1992).

In general, the rate of recombination per unit of DNA is greatest in the regions near the telomeres and least near the centromeres, as evidenced by the convergence and divergence of lines connecting the physical and genetic maps in Fig. 1. Two noncentromeric regions with extremely low rates of recombination were observed at SSC $1 \mathrm{q} 2.1 \rightarrow \mathrm{q} 2.8$ and $13 \mathrm{q} 2.3 \rightarrow \mathrm{q} 4.1$. In the physical map SSC 1 q $2.1 \rightarrow$ q 2.8 represents about $29 \%$ of the chromosome, but only $11.8 \%$ of the genetic map $(\sim 0.2 \mathrm{cM} /$ $\mathrm{Mb}$ ). Similarly, SSC $13 \mathrm{q} 2.3 \rightarrow \mathrm{q} 4.1$ comprises over $40 \%$ of the physical length of the chromosome, but only represents $6 \%$ of the genetic map $(<0.1 \mathrm{cM} / \mathrm{Mb})$. Three telomeric regions exhibited higher than expected rates of recombination at SSC $5 \mathrm{p} 1.5 \rightarrow \mathrm{p} 1.2(2.1 \mathrm{cM} / \mathrm{Mb}), 6 \mathrm{p} 1.5 \rightarrow \mathrm{p} 1.4(1.7 \mathrm{cM} / \mathrm{Mb})$, and $12 \mathrm{p} 1.5 \rightarrow \mathrm{p} 1.4(3.1 \mathrm{cM} / \mathrm{Mb})$. All of these regions are located on the short arms of their respective chromosomes and represent twice as much of the genetic map than the cytogenetic map.

Recombination per unit of DNA also appeared more frequent in small chromosomes (SSC 12, 17, and 18) than in large chromosomes (SSC 1 and 13). Based on the physical sizes of the chromosomes (Schmitz et al., 1992) and lengths of each linkage group (Rohrer et al., 1996; http://www.marc.usda.gov), a value for the rate of recombination (in $\mathrm{cM} / \mathrm{Mb}$ ) can be estimated (the physical sizes for SSC 11,14 and 18 need to be modified to include only the portion of the chromosome spanned by the linkage group). The overall value for the porcine genome is 0.88 $\mathrm{cM} / \mathrm{Mb}$. Chromosomes that displayed more than $1.2 \mathrm{cM} / \mathrm{Mb}$ were SSC 5 (1.23), 10 (1.20), 12 (1.53), and 17 (1.26), whereas chromosomes $1(0.49)$ and $13(0.54)$ had the lowest values. Chromosomes 2, 14, and 15 had the next lowest rate of recombination, ranging from 0.72 (SSC 14) to 0.79 (SSC 2). Based on the current length of the swine genetic map and the amount of DNA not represented in the map, the length of the sex-averaged autosomal map is estimated to be at least 2,250 cM.
In summary, 53 microsatellites were assigned by FISH to 18 different chromosomes. These assignments improve the integration of the physical and genetic maps in specific regions of the genome, demonstrate genomic coverage of the genetic map, and permit estimation of the regional rate of recombination.

\section{Acknowledgements}

The authors wish to acknowledge Renée Godtel for her expert technical assistance in FISH, Sherry Kluver for her help with the manuscript preparation, and Alan Archibald for his critical review of early versions of this paper. 


\section{References}

Alexander L, Smith TPL, Beattie CW, Broom MF: Construction and characterization of a large insert porcine YAC library. Mammal Genome 8:50-51 (1997).

Alexander LJ, Troyer DL, Rohrer GA, Smith TPL, Schook LB, Beattie CW: Physical assignments of 68 porcine cosmid and lambda clones containing polymorphic microsatellites. Mammal Genome 7:368-372 (1996).

Andersson L, Haley CS, Ellegren H, Knott SA, Johansson M, Andersson K, Andersson-Eklund L, EdforsLilja I, Fredholm M, Hansson I, Hảkansson J, Lundström K: Genetic mapping of quantitative trait loci for growth and fatness in pigs. Science 263:1771-1774 (1994).

Archibald AL, Haley CS, Brown JF, Couperwhite S, McQueen HA, Nicholson D, Coppieters W, Van de Weghe A, Stratil A, Winterø AK, Fredholm M, Larsen NJ, Nielsen VH, Milan D, Woloszyn N, Robic A, Dalens M, Riquet J, Gellin J, Caritez J-C, Burgaud G, Ollivier L, Bidanel J-P, Vaiman M, Renard C, Geldermann H, Davoli R, Ruyter D, Verstege EJM, Groenen MAM, Davies W, Heyheim B, Keiserud A, Andersson L, Ellegren H, Johansson M, Marklund L, Miller JR, Anderson Dear DV, Signer E, Jeffreys AJ, Moran C, Le Tissier P, Muladno, Rothschild MF, Tuggle CK, Vaske D, Helm J, Liu H-C, Rahman A, Yu T-P, Larson RG, Schmitz CB: The PiGMaP consortium linkage map of the pig (Sus scrofa). Mammal Genome 6:157-175 (1995).
Committee for the Standardized Karyotype of the Domestic Pig: Standard karyotype of the domestic pig [edited by Gustavsson I]. Hereditas 109:151157 (1988).

Georges M, Drinkwater R, King T, Mishra A, Moore SS, Nielsen D, Sargeant LS, Sorensen A, Steele MR, Zhao X, Womack JE, Hetzel J: Microsatellite mapping of a gene affecting horn development in Bos taurus. Nature Genet 4:206-210 (1993).

Lemieux N, Dutrillaux B, Viegas-Péquignot E: A simple method for simultaneous R- or G-banding and fluorescence in situ hybridization of small singlecopy genes. Cytogenet Cell Genet 59:311-312 (1992).

Lichter P. Tang CC. Call K, Hermanson G, Evans GA, Housman D, Ward DC: High-resolution mapping of human chromosome 11 by in situ hybridization with cosmid clones. Science 247:64-69 (1990).

Marklund L, Johansson Moller M, Høyheim B, Davies W, Fredholm M, Juneja RK, Mariani P, Coppieters W, Ellegren H, Andersson L: A comprehensive linkage map of the pig based on a wild pig-Large White intercross. Anim Genet 27:255-269 (1996).

Milan D, Woloszyn N, Yerle M, Le Roy P, Bonnet M, Riquet J, Lahbib-Mansais Y, Caritez J-C, Robic A, Sellier P, Elsen J-M, Gellin J: Accurate mapping of the "acid meat" RN gene on genetic and physical maps of pig chromosome 15. Mammal Genome 7:47-51 (1996).

Ponce de Leon FA, Ambady S, Hawkins GA, Kappes SM, Bishop MD, Robl JM, Beattie CW: Development of a bovine $\mathrm{X}$ chromosome linkage group and painting probes to assess cattle, sheep, and goat $X$ chromosome segment homologies. Proc natl Acad Sci, USA 93:3450-3454 (1996).
Rettenberger G, Bruch J, Beattie CW, Moran C, Fries $\mathrm{R}$, Hameister $\mathrm{H}$ : Chromosomal assignment of seventeen porcine microsatellites and genes by use of a somatic cell hybrid mapping panel. Anim Genet 26:269-273 (1995).

Robic A, Riquet J, Yerle M, Milan D, Lahbib-Mansais Y, Dubut-Fontana C, Gellin J: Porcine linkage and cytogenetic maps integrated by regional mapping of 100 microsatellites on somatic cell hybrid panel. Mammal Genome 7:438-445 (1996).

Rohrer GA, Alexander LJ, Hu Z, Smith TPL, Keele JW, Beattie CW: A comprehensive map of the porcine genome. Genome Res 6:371-391 (1996).

Schmitz A, Chaput B, Fouchet P, Guilly MN, Frelat G, Vaiman M: Swine chromosomal DNA quantification by bivariate flow karyotyping and karyotype interpretation. Cytometry 13:703-710 (1992).

Troyer DL, Xie H, Goad DW: Use of DISC-PCR to map a porcine microsatellite. Anim Biotech 6:5158 (1995).

Yerle M, Echard G, Robic A, Mairal A, Dubut-Fontana C, Riquet J, Pinton PMD, Lahbib-Mansais Y, Gellin J: A somatic cell hybrid panel for pig regional gene mapping characterized by molecular cytogenetics. Cytogenet. Cell Genet 73:194-202 (1996).

Yerle M, Lahbib-Mansais Y, Pinton P, Robic A, Goureau A, Milan D, Gellin J: The cytogenetic map of the domestic pig (Sus scrofa domestica). Mammal Genome 8:592-607 (1997). 